\title{
ПРОБЛЕМА ВОЗРАСТНОГО ЦИФРОВОГО РАЗРЫВА СОВРЕМЕННОСТИ
}

\section{Галиуллина Э.Р., Шакиров А.А., Зарипова Р.С.}

Казанский государственный энергетический университет,

г. Казань, Российская Федерация

В настоящее время в мире существуют три широкие тенденции: старение нашего населения, продолжающаяся урбанизащия человеческих обществ и растущая зависимость от информационно-коммуникационных технологий (ИКТ). Демографические изменения, ведущие к старению населения, происходят одновременно с быстрыми технологическими изменениями. В данной статье рассматриваются проблемы, с которыми сталкиваются пожилье люди в возрасте от 65 лет.

Ключевые слова: иүифровая компетентность; ичифровой разрыв; компьютерная грамотность; обучение; циифровизация.

\section{THE PROBLEM OF AGE DIGITAL TIME-BREAKING}

\section{Galiullina E.R., Shakirov A.A., Zaripova R.S.}

Kazan state power engineering University, Kazan, Russian Federation

There are currently three broad trends in the world: the aging of our population, the continuing urbanization of human societies and the growing dependence on information and communication technologies (ICT). Demographic changes leading to an aging population are occurring simultaneously with rapid technological changes. This article discusses the problems faced by older people aged 65 and over.

Keywords: digital competence; digital divide; computer literacy; learning; digitalization. 
Информационные технологии являются необходимой грамматикой современной жизни для всех людей, что приводит к постоянным политическим усилиям по обеспечению доступа каждого гражданина ИКТ и сокращению различий между теми сегментами общества, которые имеют доступ к ИКТ и те, которые не имеют. По данным правительства России, более $26 \%$ населения живут в сельских и отдаленных местах, где социальная изоляция и отсутствие доступа к услугам, станет проблемой нежели для городских жителей, которые принимают такие удобства как должное. К тому же пожилые люди менее грамотны в цифровом отношении и, следовательно, не могут получить доступ к онлайновым услугам, совершенно ясно, что есть проблема, требующая решения.

По мере расширения доступа к широкополосной связи в сельских и отдаленных районах России пожилые люди потенциально будут иметь более широкие возможности для интеграции цифровых технологий в свою повседневную жизнь и получения ряда выгод. В рамках финансируемой правительством инициативы в различных сельских районах России были созданы цифровые школы для пожилых, с тем чтобы местные жители могли расширить свое онлайновое участие и лучше понять возможности, создаваемые Российской широкополосной сетью.

В прессе и научных кругах много говорится о так называемом «цифровом разрыве» - разрыве между теми, кто имеет доступ к технологиям, компьютерам и Интернету, и теми, кто его не имеет. Ситуация может ухудшиться по мере увеличения доли пожилых людей в обществе. По оценкам, к 2020 году 16\% населения России будет 65 лет и старше. Социальные обозреватели быстро указывают на то, что информационное общество также является стареющим обществом, старение пользователей технологий привело к «дискурсивному изображению серебряных серферов»- популярному, но туманному описанию растущей группы уверенных и компетентных пожилых пользователей ИКТ. Учитывая, что использование компьютеров и интернета отрицательно коррелирует с возрастом, утопическое видение «серебряных серферов» может 
быть преувеличением. Исследования показывают, что, хотя пожилые люди являются самой быстрорастущей демографической группой в развитых странах, использование ИКТ пожилыми людьми отстает от других групп. Становится все более очевидным, что, хотя некоторые пожилые люди действительно умеют пользоваться компьютерами и интернетом, тем не менее существует возрастная цифровая пропасть. При обсуждении использования цифровых технологий пожилых необходимо различать характеристики нынешнего и будущих поколений онлайн-пожилых. Следующее поколение пожилых людей (56\% из тех, кто в настоящее время в возрасте 50-64 лет - ранние бэби-бумеры) будут использовать компьютеры и интернет на работе. Это говорит о том, что профессия и рабочее место являются ключевыми детерминантами использования Интернета. Трудовая деятельность является одним из основных факторов приобретения и поддержания компьютерных навыков и доступа к Интернету, а также создания благоприятных условий для овладения этими навыками. Предполагается, что, поскольку нынешнее поколение бэби-бумеров не имело возможность стать компетентным в использовании ИКТ, следующее поколение пожилых людей не столкнется с таким же исключением из «информационной супермагистрали». Однако невозможно предсказать, будут ли бэби-бумеры, приближающиеся к пенсионному возрасту, продолжать использовать ИКТ при выходе на пенсию. Учитывая быстрые темпы изменения технологии, вероятно, что, если взрослые не будут продолжать совершенствовать свои навыки, имеющиеся у них знания в области ИКТ станут излишними в краткосрочной и среднесрочной перспективе.

Пожилые люди сталкиваются с определенным набором препятствий для использования и внедрения ИКТ в более позднем возрасте, включая беспокойство по поводу технологии (техногенный страх), отсутствие интереса, барьеры в отношении здоровья или инвалидности, отсутствие возможности обучения и стоимость. И эти барьеры не могут быть смягчены просто потому, что будущие поколения в настоящее время используют ИКТ на рабочем месте. В отличие 
от большинства повседневных обстоятельств, когда возраст обычно ассоциируется с опытом, в цифровую эпоху наблюдается обратная тенденция: молодые пользователи более опытны в использовании компьютеров, чем более старые. В связи с этим крайне важно, чтобы нынешнее и будущие поколения пожилых людей имели возможность использовать ИКТ, с тем чтобы последние, которые уже обладают цифровой компетенцией, не сталкивались с проблемами изоляции и маргинализации, которые сопровождают растущее значение деятельности, опосредованной ИКТ, в современной социальной жизни.

Ситуация в сфере информационных технологий меняется стремительно. Новые возможности создают предпосылки для развития человека и общества. Виртуальное пространство открывает перед странами, которые не были лидерами на мировой арене, возможность вырваться вперед, определять формирование современной цивилизации. Информационные технологии содержат большой потенциал для дальнейшего развития человечества, преодоления существующих противоречий в сфере политики и экономики, но могут, напротив, стать причиной углубления дифференций между людьми - между теми, кто возьмет на вооружение достижения XXI века, и теми, кто не сможет ими воспользоваться.

\section{Список литературы}

1. Ромашкин В.А. Информационные технологии и их внедрение в процесс обучения / В.А. Ромашкин, А.А. Шакиров, Р.С. Зарипова // «Цифровая культура открытых городов»: Сборник материалов Международной научно-практической конференции. Екатеринбург. 2018. С. 440-443.

2. Басаргин В.Я. Влияние цифровых технологий на урбанизацию / В.Я. Басаргин, Р.С. Зарипова, О.А. Пырнова // «Цифровая культура открытых городов»: Сборник материалов Международной научнопрактической конференции. Екатеринбург. 2018. С. 13-15.

3. Пырнова О.А. Интернет как средство обучения / О.А. Пырнова, P.С. Зарипова // International Journal of Advanced Studies in Education and Sociology. 2018. № 2. C. 41-44. 


\section{References}

1. Romashkin V.A. Informacionnye tekhnologii i ih vnedrenie v process obucheniya / V.A. Romashkin, A.A. SHakirov, R.S. Zaripova // «Cifrovaya kul'tura otkrytyh gorodov»: Sbornik materialov Mezhdunarodnoj nauchno-prakticheskoj konferencii. Ekaterinburg. 2018. S. 440-443.

2. Basargin V.Ya. Vliyanie cifrovyh tekhnologij na urbanizaciyu / V.Ya. Basargin, R.S. Zaripova, O.A. Pyrnova // «Cifrovaya kul'tura otkrytyh gorodov»: Sbornik materialov Mezhdunarodnoj nauchno-prakticheskoj konferencii. Ekaterinburg. 2018. S. 13-15.

3. Pyrnova O.A. Internet kak sredstvo obucheniya / O.A. Pyrnova, R.S. Zaripova // International Journal of Advanced Studies in Education and Sociology. 2018. № 2. S. 41-44. 